Article

\title{
The Effects of Cultivar, Nitrogen Supply and Soil Type on Radiation Use Efficiency and Harvest Index in Spring Wheat
}

\author{
Xizi Wang ${ }^{\oplus}$, Svend Christensen $* \mathbb{D}$, Jesper Svensgaard, Signe M. Jensen $₫$ and Fulai Liu * \\ Department of Plant and Environmental Sciences, University of Copenhagen, Højbakkegaard Alle 13, \\ 2630 Taastrup, Denmark; xiwa@plen.ku.dk (X.W.); jsv@concito.dk (J.S.); smj@plen.ku.dk (S.M.J.) \\ * Correspondence: svc@plen.ku.dk (S.C.); fl@plen.ku.dk (F.L.); Tel.: +45-35-33-33-92 (F.L.)
}

Received: 17 July 2020; Accepted: 11 September 2020; Published: 14 September 2020

\begin{abstract}
There is an urgent need among plant breeders for a deeper understanding of the links between wheat genotypes and their ability to utilize light for biomass production and their efficiency at converting the biomass into grain yield. This field trail was conducted to investigate the variations in radiation use efficiency (RUE) and harvest index (HI) of four spring wheat cultivars grown on two soil types with two nitrogen (N) fertilization levels. Grain yield (GY) was significantly higher with $200 \mathrm{~kg} \mathrm{~N} \mathrm{ha}^{-1}$ than $100 \mathrm{~kg} \mathrm{~N} \mathrm{ha}^{-1}$ and on clay soil than on sandy soil, and a similar trend was observed for shoot dry matter (DM) at maturity. RUE and HI was neither affected by cultivar nor $\mathrm{N}$-fertilization, but was affected by soil type, with a significantly higher RUE and HI on clay than on sandy soil. The differences of water holding capacity between the two soil types was suggested to be a major factor influencing RUE and HI as exemplified by the principal component analysis. Thus, to achieve a high RUE and/or HI, sustaining a good soil water status during the critical growth stages of wheat crops is essential, especially on sandy soils with a low water holding capacity.
\end{abstract}

Keywords: harvest index; nitrogen; radiation use efficiency; water availability; wheat

\section{Introduction}

Bread wheat (Triticum aestivum) is one of the most globally cultivated crops, grown in more than 85 countries with 750 million tonnes produced each year. It contributes to about $20 \%$ of the total dietary calories and proteins worldwide [1]. Since the Green Revolution, the yield increase of wheat has been mostly attributed to genetic gains in breeding seen as an increased ratio of grain yield to total biomass (i.e., harvest index, HI) [2]. Studies have shown that the HI can be significantly affected by environmental factors such as the water availability during crop reproductive development [3]. In addition, it has been found that an optimized nitrogen $(\mathrm{N})$ fertilization at different growth stages and supplementary irrigation at anthesis could increase the $\mathrm{HI}$ and the grain yield in wheat crops [4]. In a rainfed production system, the soil water holding capacity would be an important factor affecting the HI, particularly under terminal drought conditions [5]. However, it remains largely unknown how different soil types with contrasting textures affect the $\mathrm{HI}$ in different wheat cultivars.

Dry matter (DM) is the product of accumulated intercepted photosynthetically active radiation (APAR) and the radiation use efficiency (RUE). In wheat, both an increased HI and an increased DM are beneficial to the yield. Since the 1980s, there has been very little progress in enhancing the HI of spring wheat [6], and the yield increase in wheat has mainly been associated with genetic gains of improved photosynthesis, crop growth rate and RUE within the semi-dwarf bread wheats $[7,8]$. Therefore, any progress in enhancement of RUE will lead to a significant improvement in DM and grain yield in wheat crops if the HI is maintained or increased. Historic evidence has indicated 
that genetic gain by conventional breeding increased RUE along with grain yield [9], though the progress has been very slow [10]. This could be due to the fact that, besides genotype, RUE can be affected by both climatic (i.e., temperature and soil moisture availability) and management factors (i.e., irrigation and $\mathrm{N}$ fertilization) $[11,12]$. Under non-stressed conditions, the RUE of wheat varies from 1.46 to $2.93 \mathrm{~g} \mathrm{DM} \mathrm{MJ}^{-1}[13,14]$. In Denmark, an average RUE value of winter wheat between 2.6 and $2.7 \mathrm{~g} \mathrm{DM} \mathrm{MJ}^{-1}$ was reported $[15,16]$. Soil water deficits reduce RUE by reducing both the APAR due to a reduced leaf area index and the photosynthetic rate caused by a lower stomatal conductance $[17,18]$. RUE could also be affected by $N$ nutrition. It often increases with increasing $\mathrm{N}$-fertilization rate $[19,20]$, yet a strong negative linear relationship between $\mathrm{N}$ concentration in the DM and RUE at harvest was found in wheat [15].

It is well known that both HI and RUE are dependent on genotype (G), environment (E) and management $(\mathrm{M})$, as well as their interactions, i.e., $\mathrm{G} \times \mathrm{E} \times \mathrm{M}$ [21]. Although the number of combinations is a challenge for dissecting the contribution of each component to the HI and RUE, the recent technological advances in the development of high throughput phenotyping platforms enable fast screening for high $\mathrm{HI}$ and RUE of a large number of genotypes grown under a variety of environmental conditions and management practices [22]. In line with this, it has been suggested that new opportunities to drive increased productivity would be sought by capturing future $\mathrm{G} \times \mathrm{E} \times \mathrm{M}$ synergies [21].

The objective of this study was to dissect the $G \times E \times M$ interactions for four different wheat cultivars, two soil types and two N-fertilization levels, by analyzing the variation in the HI and RUE. Furthermore, we discussed how cultivars, soil type and N-fertilization level affect $\mathrm{HI}$ and RUE and how it could be used to calibrate simple or more advanced mathematical models describing growth and yield relationships for different cultivars under variable environmental and management conditions.

\section{Materials and Methods}

\subsection{Experimental Setup}

The trials were carried out during 2013 and 2014 at the field research station, Hoejbakkegaard, Taastrup ( $\left.56^{\circ} \mathrm{N}, 9^{\circ} \mathrm{E}\right)$, Department of Plant and Environmental Sciences, University of Copenhagen, Denmark. The experimental setup has previously been described partially elsewhere [23], here only a brief description is given. The experiment was designed as a randomized complete block design with two levels of $\mathrm{N}$ fertilization, four spring wheat varieties and four replicates. The trials were carried out at two sites within a distance of $430 \mathrm{~m}$, of two different soil types: (a) a fine clay loam soil with $55-59 \%$ sand, $10-15 \%$ clay and $0-30 \%$ silt and an available water capacity of $160 \mathrm{~mm}$ in the root zone of spring sown cereals; and (b) a sandy loam soil with $65-95 \%$ sand, $5-10 \%$ clay and an available water capacity of $125 \mathrm{~mm}$ in the root zone of spring sown cereals. The available water capacity of the two soil types was taken from a textbook summarizing the research on the physical properties of these two soil types in the area around Hoejkakkegaard, Taastrup [24].

The applied $\mathrm{N}$ was $100 \mathrm{~kg} \mathrm{ha}^{-1}$ and $200 \mathrm{~kg} \mathrm{ha}^{-1}$, respectively, and applied as base fertilizer. Four commercial spring wheat varieties, Quintus (A), Scirocco (B), Økilde (C) and Hovsa (D) were selected based on differences in their early vigor, crop height and earliness of maturity from official testing of the varieties and information from the breeding companies. The plot size was $12 \mathrm{~m} \times 1.5 \mathrm{~m}$ and each plot had 10 rows of plants. The experiment was managed in a conventional way, in which plough, rotor harrowing, sowing, phosphate and potassium fertilizer and herbicide+/fungicide were applied, according to local standards. The field trials were carried out during April-August in 2013 and 2014. The crop was sown 13 days earlier in 2014 than in 2013. The climatic parameters, including precipitation, air temperature, radiation, and potential evapotranspiration recorded at the local climate station, are shown in Figure 1. 

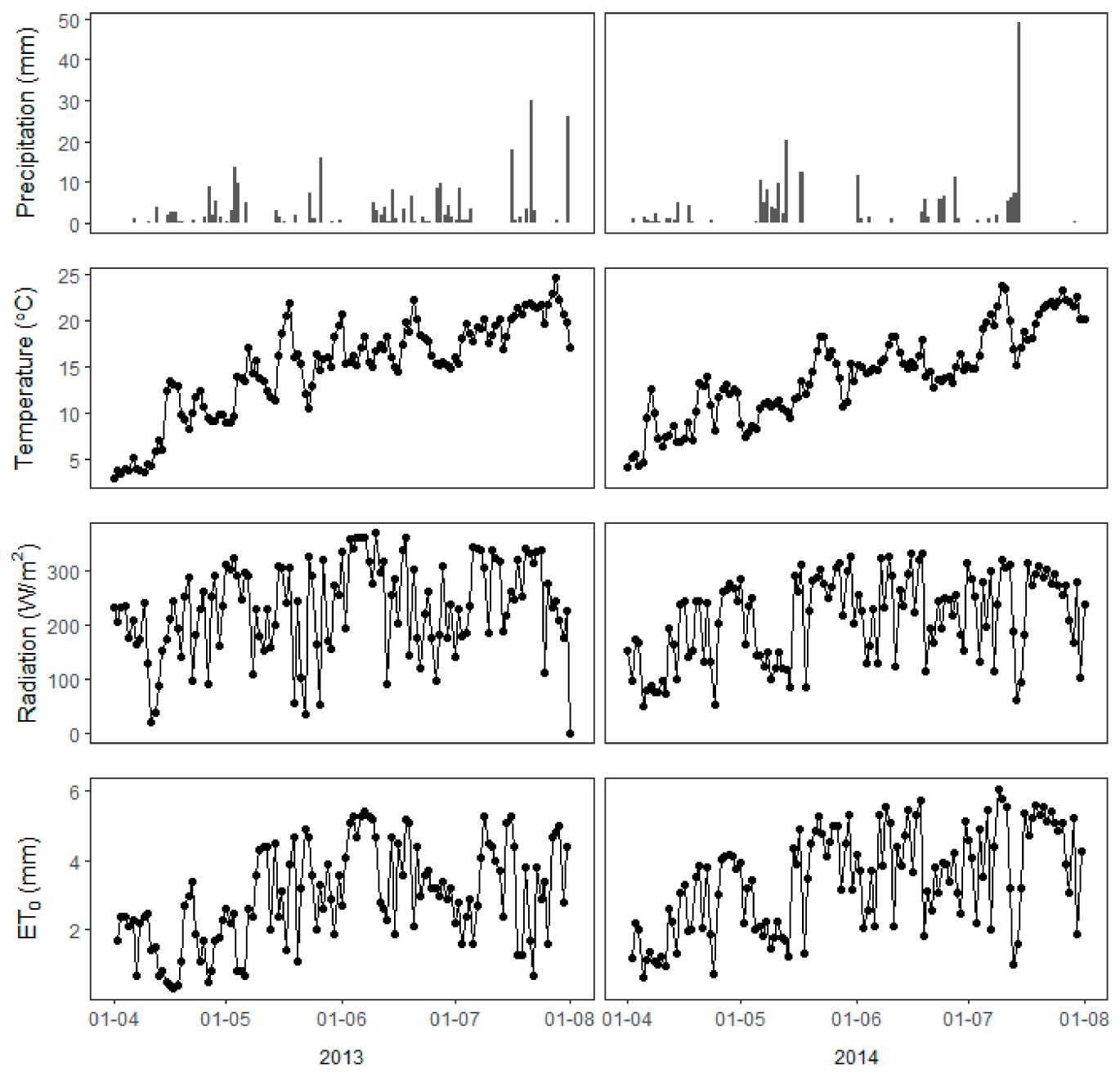

Figure 1. The daily precipitation ( $\mathrm{mm})$, mean temperature (Celsius), incoming radiation $\left(\mathrm{W} / \mathrm{m}^{2}\right)$ and potential evapotranspiration (ET0) during the growing season 2013 and 2014, measured at the local weather station.

Table 1 summarizes the dates of measurements of the fraction of intercepted photosynthetically active radiation (fPAR) and aboveground DM and grain yield. PAR was measured at the same time at the soil surface and above the canopy with two LICOR line quantum sensors. One sensor was inserted between the rows, below the leaves of the crop at six different locations within each plot. The other sensor was placed on the top of the canopy. All measurements were carried out within one hour before and after solar noon.

All four spring wheat cultivars emerged from early May and reached the tillering growth stage within two weeks. Then, the first measurement of fPAR was conducted, which was ca. $25 \%$ for all cultivars. The fPAR increased gradually up to $80 \% \sim 90 \%$ in early-mid June. By then, the canopy structure was dense with multiple leaf layers.

Following the schedule in Table 1, after each fPAR measurement, $0.5 \mathrm{~m}^{2}$ of the wheat plants per plot were sampled and the aboveground DM was determined after oven drying at $70{ }^{\circ} \mathrm{C}$ for $48 \mathrm{~h}$. At maturity, all plots were harvested and the grain yield (GY) was determined. HI was calculated as the ratio of GY to aboveground DM. 
Table 1. Time schedule of measurements of fraction of PAR at the soil surface (fPAR) and aboveground dry matter (DM) at different calendar dates and growth stages for the field trials in 2013 and 2014.

\begin{tabular}{ccccc}
\hline Growth Stage & fPAR & DM & 2013 (dd-mm) & 2014 (dd-mm) \\
\hline Sowing & & & $14-04$ & $04-04$ \\
Seedling growth & & & $16-05$ & $25-04$ \\
Tillering & + & + & $31-05$ & $16-05$ \\
Stem-elongation & + & & $12-06$ & $26-05$ \\
Booting & + & + & $18-06$ & $07-06$ \\
Heading & + & & $29-06$ & $16-06$ \\
Flowering & + & + & $11-07$ & $28-06$ \\
Grain filling & + & & $19-07$ & $03-07$ \\
Ripening & + & + & $26-07$ & $18-07$ \\
Final harvest & + & & $10-08$ & $26-08$ \\
\hline
\end{tabular}

\subsection{Calculations}

The fPAR is the fraction of incident PAR $(400-700 \mathrm{~nm})$ intercepted by the canopy. The fPAR of each plot was calculated as:

$$
\mathrm{fPAR}=1-\mathrm{Q}_{\mathrm{T}} / \mathrm{Q}
$$

where $\mathrm{Q}$ was the incoming PAR $\left(\mathrm{MJ} \mathrm{m}^{-2} \mathrm{~d}^{-1}\right)$ measured above the canopy with the LI-191SB, $\mathrm{Q}_{\mathrm{T}}$ was the transmitted PAR (MJ m ${ }^{-2} \mathrm{~d}^{-1}$ ) measured with the LI-191SB at the soil surface. The daily fPAR of each plot was estimated by linear interpolation between the dates of the average of the six measurements of fPAR values. The daily intercepted PAR (MJ m $\left.{ }^{-2} \mathrm{~d}^{-1}\right)$ was calculated as:

$$
\operatorname{IPAR}(d)=\operatorname{fPAR}(\mathrm{d}) \times \operatorname{PAR}(\mathrm{d})
$$

where PAR(d) (MJ m $\left.{ }^{-2} \mathrm{~d}^{-1}\right)$ was the daily PAR calculated as $48 \%$ of the daily incoming shortwave solar radiation $(300-2800 \mathrm{~nm})$ measured at the local weather station.

The accumulated intercepted PAR (APAR, $\mathrm{MJ} \mathrm{m}^{-2}$ ) was calculated for the number of growing days corresponding to that for DM measurements:

$$
\operatorname{APAR}=\Sigma \operatorname{PAR}(\mathrm{d})
$$

\subsection{Statistics}

Sample characteristics of aboveground DM and APAR were analyzed for each date separately using a linear mixed model with the combination of soil type, $\mathrm{N}$ and cultivar as fixed effect and block as random effect. RUE was estimated as the slope of the linear association between APAR and DM assuming a zero intercept. The association was estimated in a linear mixed model allowing a separate slope for each combination of soil type, $\mathrm{N}$ and cultivar with a random slope for plot, block and year and an exponential correlation structure to account for the serial correlation of repeated measurements within the plots. Data on grain yield (GY) and total biomass were analyzed using mixed ANOVA with the combination of soil type, $\mathrm{N}$ and cultivar as fixed effects and block and year as random effects. The harvest index (HI) was estimated using an after-fitting approach combining the estimates for GY and total biomass [25].

Model assumptions were assessed by visual inspection of residuals and predicted random effects in residual- and QQ-plots. F-tests were used to evaluate the overall effects of interactions and main effects. Post hoc pairwise comparisons were based on the estimated models. Principal component analysis (PCA) was performed on the measured variables on plot levels (i.e., DM, GY, HI, and RUE). Variables were centered and scaled before PCA. All statistical analyses were made using the statistical software $R$ version 3.6.1 [26]. In particular, the packages nlme [27] and lme4 [28] were used for fitting linear mixed models, multcomp [29] for pairwise comparisons and mmmVcov [30] for estimating the joint covariance matrix in the after-fitting approach used for the harvest index. 


\section{Results}

The APAR and DM measured on four dates (Table 1) during the growing seasons in 2013 and 2014, respectively, are shown in Figure 2. In 2013, the APAR was similar among different combinations of variety, $\mathrm{N}$ level and soil type at each of the four growth stages; whereas in 2014, plants grown on the sandy soil with $100 \mathrm{~kg} \mathrm{ha}^{-1} \mathrm{~N}$ supply showed a lower APAR than those with $200 \mathrm{~kg} \mathrm{ha}^{-1} \mathrm{~N}$ supply at flowering and ripening stages compared to other treatments. The genetic variation between the four chosen cultivars was not evident as they exhibited a similar APAR value at each measuring date in 2013, while in 2014 there was a tendency that, on sandy soil with $100 \mathrm{~kg} \mathrm{~N}$ supply, the APAR of cultivar $\mathrm{C}$ was lower than that of other cultivars (Figure 2). The DM increased linearly from the tillering stage to ripening stage. At the flowering and ripening stages, DM on the clay soil was significantly higher than that on the sandy soil, in both years. Compared with 2014, DM on the sandy soil was higher on the four sampling dates in 2013; while on the clay soil, DM was higher from tillering to flowering stage in 2013 and reached the same level as 2014 at the ripening stage (Figure 2).

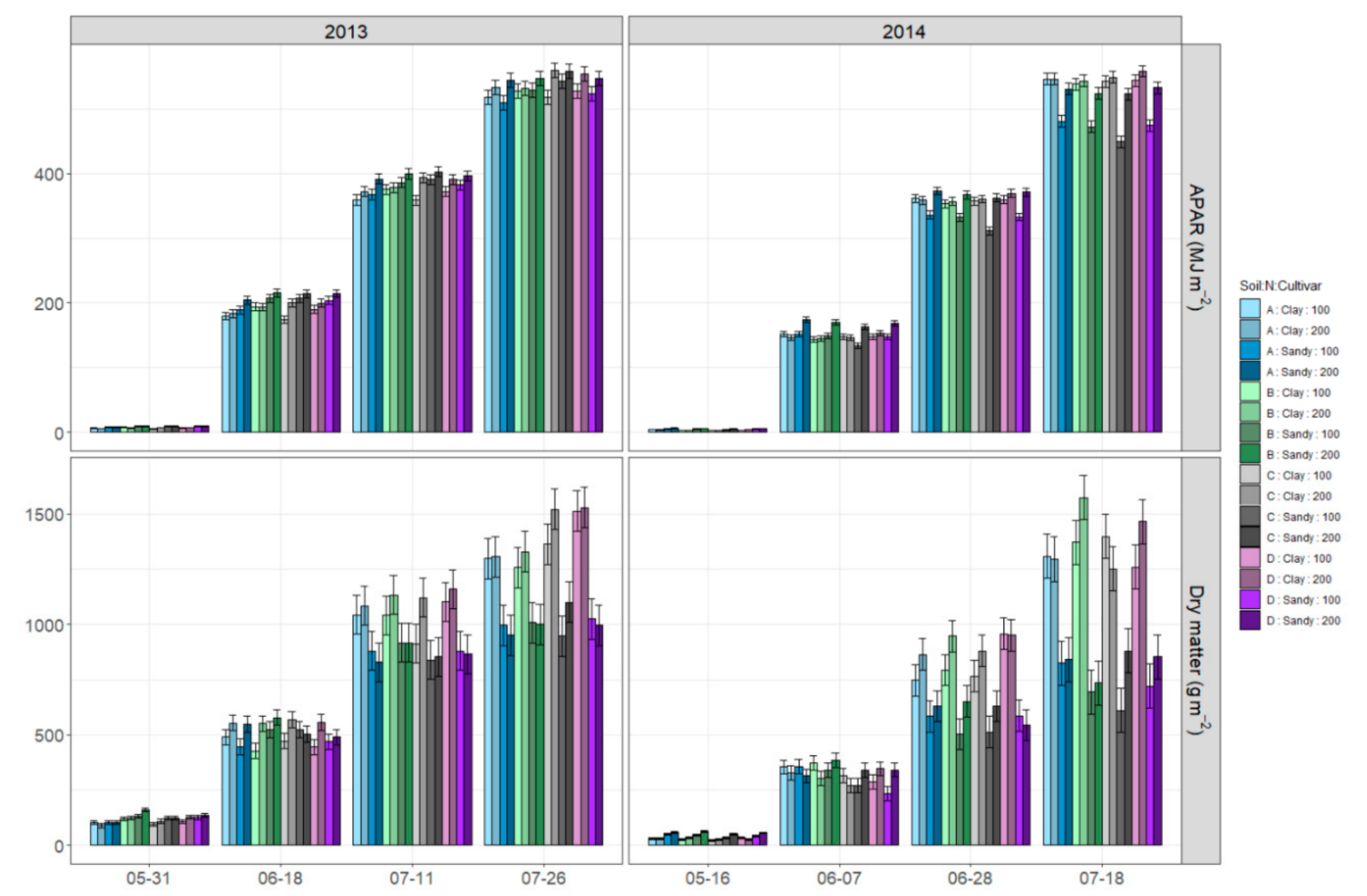

Figure 2. Estimated mean accumulated intercepted photosynthetic active radiation (APAR) and aboveground dry matter (DM) of the two soil types, four varieties and two nitrogen levels for each time point in 2013 (left) and 2014 (right). Error bars represent standard error of the means. A, B, C, D denote the spring wheat varieties Quintus, Scirocco, Økilde and Hovsa, respectively.

Across the two years, DM and GY at final harvest were significantly affected by soil type and $\mathrm{N}$ level and being higher on clay than on sandy and with $200 \mathrm{~kg} \mathrm{~N} \mathrm{ha}^{-1}$ than with $100 \mathrm{~kg} \mathrm{~N} \mathrm{ha}^{-1}$ (Table 2). On the clay soil, the Hovsa cultivar (D) had the highest GY and DM under both N-fertilization levels. On clay soil with $100 \mathrm{~kg} \mathrm{~N} \mathrm{ha}^{-1}$, the cultivar Hovsa possessed significantly greater GY and DM than Scirocco (B); while under $200 \mathrm{~kg} \mathrm{~N} \mathrm{ha}^{-1}$, the cultivar Quinus (A) had the lowest GY, which was significantly lower than that of Hovsa. 
Table 2. Estimated radiation use efficiency (RUE, the slope of linear regression between APAR and DM through origin), grain yield (GY), total aboveground dry matter (DM) and harvest index (HI) of the different soil types, cultivars and nitrogen-levels across 2013 and 2014. Estimates are presented with standard error of the means. Estimates with the same letters are not significantly different statistically at $p=0.05$ level.

\begin{tabular}{|c|c|c|c|c|c|c|}
\hline Soil Type & N (kg ha $\left.{ }^{-1}\right)$ & Cultivar & RUE (g MJ-1) & GY $\left(\mathrm{Mg} \mathrm{ha}^{-1}\right)$ & DM (Mg ha $\left.{ }^{-1}\right)$ & HI (\%) \\
\hline \multirow[t]{8}{*}{ Clay } & 100 & A & $2.47 \pm 0.19 b$ & $6.72 \pm 0.39 \mathrm{ce}$ & $13.53 \pm 1.01 \mathrm{bd}$ & $49.67 \pm 1.91 \mathrm{ef}$ \\
\hline & & B & $2.47 \pm 0.19 b c$ & $6.19 \pm 0.39 c$ & $12.68 \pm 1.01 \mathrm{~b}$ & $48.84 \pm 2.23 \mathrm{def}$ \\
\hline & & C & $2.52 \pm 0.19 \mathrm{bd}$ & $6.58 \pm 0.39 \mathrm{~cd}$ & $13.89 \pm 1.01 \mathrm{bd}$ & $47.39 \pm 1.66 \mathrm{bde}$ \\
\hline & & $\mathrm{D}$ & $2.63 \pm 0.19 \mathrm{bd}$ & $7.05 \pm 0.39 \mathrm{de}$ & $14.11 \pm 1.01 \mathrm{cde}$ & $49.97 \pm 1.48 \mathrm{f}$ \\
\hline & 200 & A & $2.50 \pm 0.19 \mathrm{bd}$ & $6.46 \pm 0.39 \mathrm{~cd}$ & $13.12 \pm 1.01 \mathrm{bc}$ & $49.24 \pm 1.48$ ef \\
\hline & & B & $2.73 \pm 0.19 \mathrm{~d}$ & $6.74 \pm 0.39 \mathrm{ce}$ & $13.86 \pm 1.01 \mathrm{bd}$ & $48.60 \pm 1.42 \mathrm{ce}$ \\
\hline & & $\mathrm{C}$ & $2.54 \pm 0.19 \mathrm{bd}$ & $6.99 \pm 0.39 \mathrm{de}$ & $15.22 \pm 1.01 \mathrm{e}$ & $45.91 \pm 1.33 \mathrm{ad}$ \\
\hline & & $\mathrm{D}$ & $2.71 \pm 0.19 \mathrm{~cd}$ & $7.22 \pm 0.39 \mathrm{e}$ & $14.59 \pm 1.01 \mathrm{de}$ & $49.48 \pm 1.34 \mathrm{ef}$ \\
\hline \multirow[t]{8}{*}{ Sandy } & 100 & A & $1.94 \pm 0.19 a$ & $3.52 \pm 0.39 \mathrm{ab}$ & $7.85 \pm 1.01 \mathrm{a}$ & $44.91 \pm 2.76 \mathrm{acd}$ \\
\hline & & B & $1.83 \pm 0.19 a$ & $3.36 \pm 0.39 a b$ & $7.43 \pm 1.01 \mathrm{a}$ & $45.20 \pm 2.93 \mathrm{bde}$ \\
\hline & & $\mathrm{C}$ & $1.71 \pm 0.19 \mathrm{a}$ & $3.09 \pm 0.39 a$ & $7.34 \pm 1.01 \mathrm{a}$ & $42.08 \pm 2.94 \mathrm{a}$ \\
\hline & & $\mathrm{D}$ & $1.85 \pm 0.19 a$ & $3.26 \pm 0.39 a b$ & $7.73 \pm 1.01 \mathrm{a}$ & $42.15 \pm 3.21 \mathrm{ab}$ \\
\hline & 200 & A & $1.79 \pm 0.19 a$ & $3.80 \pm 0.39 b$ & $8.51 \pm 1.01 \mathrm{a}$ & $44.70 \pm 2.55 \mathrm{ad}$ \\
\hline & & B & $1.82 \pm 0.19 a$ & $3.45 \pm 0.39 \mathrm{ab}$ & $7.93 \pm 1.01 \mathrm{a}$ & $43.51 \pm 3.33 \mathrm{acd}$ \\
\hline & & $\mathrm{C}$ & $1.88 \pm 0.19 a$ & $3.57 \pm 0.39 \mathrm{ab}$ & $8.58 \pm 1.01 \mathrm{a}$ & $41.65 \pm 2.81 \mathrm{a}$ \\
\hline & & $\mathrm{D}$ & $1.78 \pm 0.19 a$ & $3.45 \pm 0.39 \mathrm{ab}$ & $8.02 \pm 1.01 \mathrm{a}$ & $43.00 \pm 2.73 \mathrm{ab}$ \\
\hline
\end{tabular}

In the multifactorial analyses of RUE, no interactions between soil type, $\mathrm{N}$ supply, and cultivar were found (all $p>0.2$ ), and there were also no main effects of cultivar and N supply detected (both $p>0.2$ ). However, RUE was significantly affected by soil type $(p<0.0001)$, with the plants grown on the clay soil having greater RUE than on sandy soil. Similarly, HI was only affected by soil type with a greater HI for plants grown on clay soil than on sandy soil (Table 2 and Figure 3). Among the four cultivars, cultivar C had the lowest $\mathrm{HI}$ on both sandy and clay as compared to other cultivars at each N levels (Table 2).

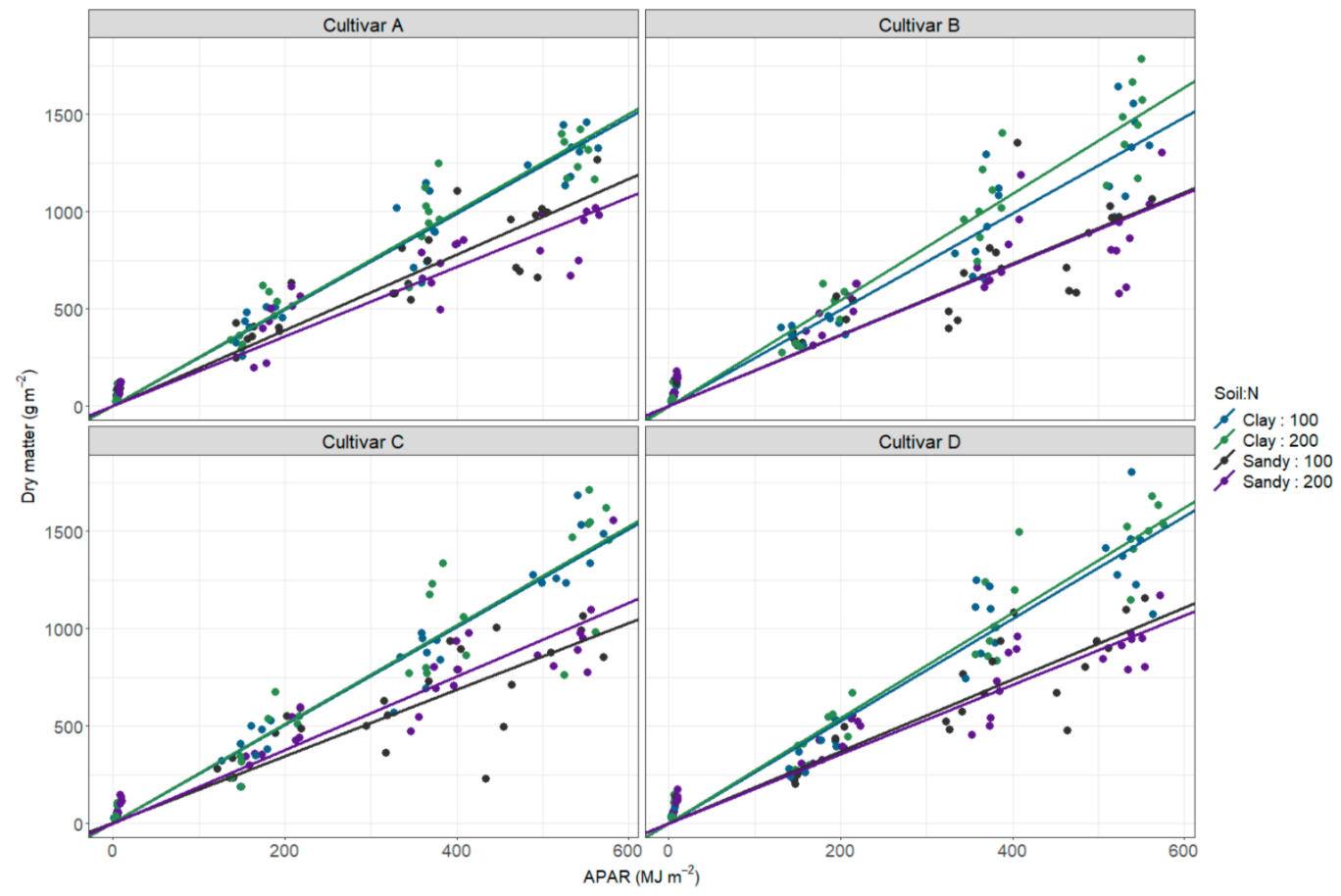

Figure 3. Linear regressions between aboveground dry matter (DM) and accumulated intercepted photosynthetic active radiation (APAR) for each nitrogen level and soil type across the four wheat cultivars A, B, C and D (Quintus, Scirocco, Økilde and Hovsa, respectively). The slopes of the regression lines represent the radiation use efficiency (RUE). The slopes were estimated from a linear mixed model with a forced intercept through the origin. 
The PCA plot further confirmed the effects of the three factors, i.e., cultivar, soil type and $\mathrm{N}$ level, on the measured parameters including DM, GY, HI, and RUE (Figure 4). PC1 explained $76.73 \%$ of the variance, whereas PC2 explained $13.22 \%$ of the variance. PC1 separated the two soil types where the clay soil was generally clustered to the left and sandy soil to the right on the plot. All of the four parameters added positive contribution to the clustering of the clay soil. $\mathrm{N}$-fertilization level was basically separated by PC2 though there was large overlap between the two N levels for each soil type, while the four cultivars scattered randomly in the plot in the clustering of each soil type without a clear pattern.

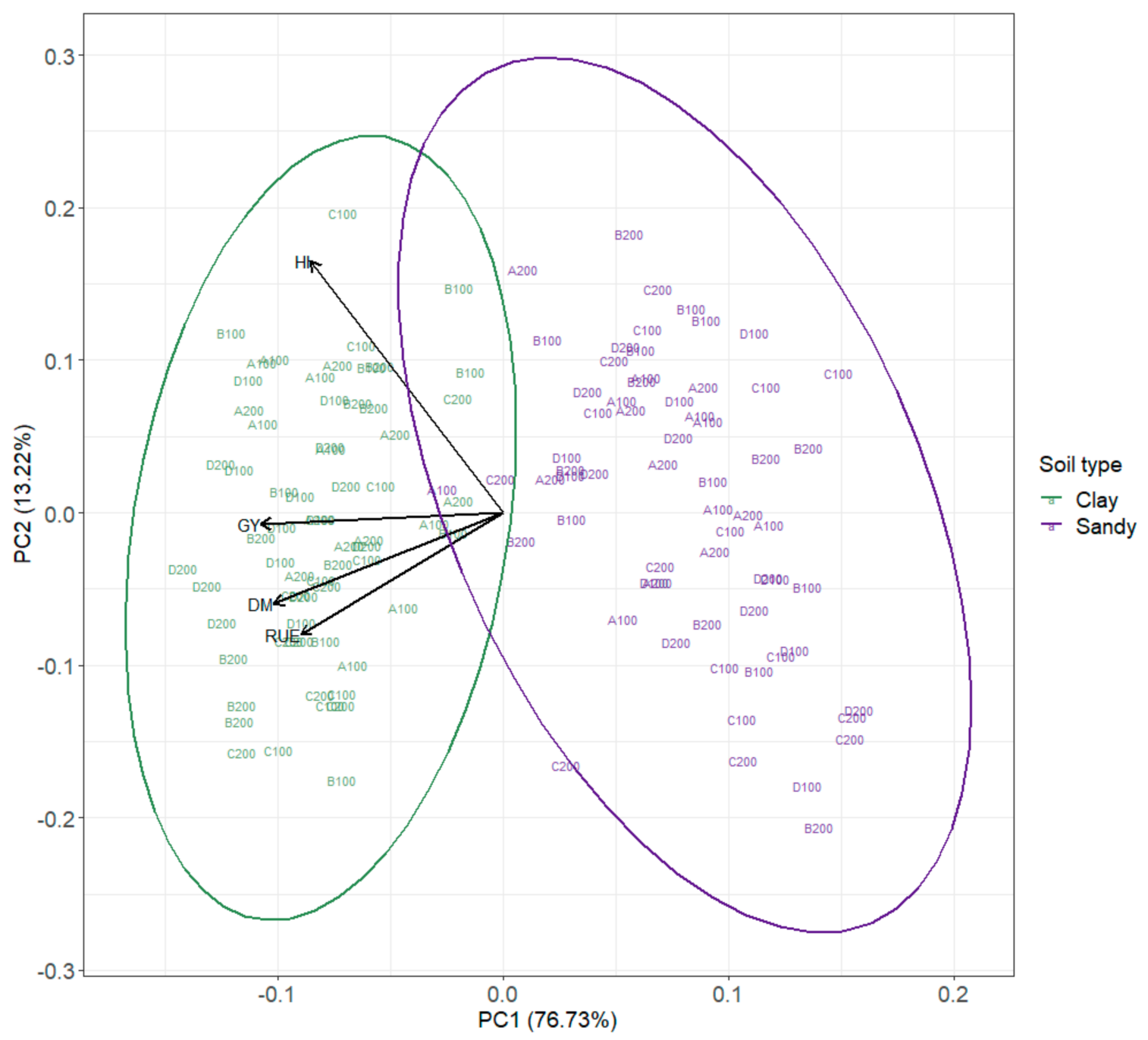

Figure 4. Principal component analyses (PCA) of the selected parameters measured on four spring wheat cultivars (A, B, C, and D-Quintus, Scirocco, Økilde and Hovsa, respectively) grown on clay or sandy soil with 100 or $200 \mathrm{~kg} \mathrm{~N}^{-1}$ supply. The parameters are aboveground dry matter (DM), grain yield (GY), harvest index (HI), and radiation use efficiency (RUE).

\section{Discussion}

$\mathrm{HI}$ and RUE are the most important parameters for predicting crop yield [11]. Increase in HI has been the main target of enhancing grain yield in wheat since the 1960s [31], which increased from 35\% in 1951-1955 to 50\% in 1995-2013 [32-34], and could reach a maximal value of $62 \%$ [35] in modern winter wheat. In the present study, HI ranged between $42 \%$ and $50 \%$ and was significantly greater for plants grown on clay soil than on sandy soil and with high $\mathrm{N}$-fertilization level than with low 
N-fertilization level. Additionally, compared to other cultivars, cultivar Hovsa possessed the highest $\mathrm{HI}$ when grown on clay soil (Table 2). Thus, $\mathrm{HI}$ is responsive to $\mathrm{G} \times \mathrm{E} \times \mathrm{M}$ interaction, though among these factors, soil type had the most pronounced effect (Table 2). One reason behind this could be that the clay soil holds much more plant available water than the sandy soil does, i.e., $160 \mathrm{~mm}$ vs. $125 \mathrm{~mm}$. Given a similar leaf area index as exemplified by the APAR values during the growth season, the water consumption would be quite similar between the crops grown on the two soil types. Under such circumstances, the soil water deficits would be much larger on sandy soil than on clay soil, especially in 2014 when the precipitation was low during the growth season, i.e., $216 \mathrm{~mm}$, which would have caused more severe drought stress to the crop resulting in a lowered HI on sandy soil than on clay soil. In line with this, early studies have demonstrated that $\mathrm{HI}$ of wheat cultivars showed a positive linear relationship to crop water consumption after anthesis [3]. In addition, studies have also indicated that $\mathrm{HI}$ of wheat genotypes tends to increase with increasing irrigation volume [4]. Therefore, sufficient water supply during the growth season is crucial for achieving a high $\mathrm{HI}$ in wheat cultivars.

The HI values obtained from this study are within the range (i.e., $40 \%$ to $50 \%$ ) reported in literature for modern wheat cultivars [4,34], thus further improvements in GY will rely more on increases in DM [36], which is the product of APAR times RUE. Any improvement in either APAR or RUE would bring about an increased DM, though there is a feedback between the two variables. APAR is determined by the leaf area and plant type [37]. An optimal crop canopy is able to effectively intercept solar radiation, thereby enhancing DM [38]. It has been suggested that wheat cultivars with early vigor, i.e., large leaf area index (LAI) during early growth stages, would have a greater RUE because photosynthesis is more efficient at low vapor pressure deficit (VPD) [39]. Thus, a real time estimation of LAI during crop development will lead to a better prediction of APAR, and this can be achieved by using advanced field phenotyping techniques measuring crop coverage or the normalized difference vegetation index (NDVI) [23]. In the present study, the four wheat cultivars showed differences in early vigor and vegetative growth from measurements of NDVI $[23,40]$. Genotypic differences in APAR were expected as some cultivars have early growth and flowering and early senescence, while other cultivars have later growth and flowering but stay green with max leaf area in a longer period before senescence. In this "stay green period" irradiance is high and thus interception with max leaf area is high, which leads to high APAR. However, the genetic variation between the four chosen cultivars must have been minor in terms of phenology and they exhibited a similar APAR value at each measuring date in 2013, indicating that the LAI could be also similar among the cultivars, soil and N fertilization treatments (Figure 2). Unlike the changes in APAR, the DM varied significantly among the treatments, particularly between the two soil types where DM was significantly greater on clay soil than on sandy soil (Figure 2). Obviously, this difference in DM was attributed mainly to the difference in RUE as illustrated in Figure 3 and Table 2, where RUE was significantly lower in crops grown on sandy soil than on clay soil.

In the present study, RUE was neither affected by cultivar nor $\mathrm{N}$-fertilization level (Figure 3 and Table 2). In disagreement with this, earlier studies reported significant differences of RUE between wheat genotypes [41,42]. A possible explanation could be that the cultivars that we have chosen are genetically related and therefore do not represent the potential genotypic variation of RUE. Nonetheless, the maximum RUE values found in this study are within in the range of those (i.e., 1.46 to $2.93 \mathrm{~g} \mathrm{DM} \mathrm{MJ}^{-1}$ ) reported for different wheat genotypes [13,14]. The lower RUE value of wheat grown on sandy soil than on clay soil could be due to the inability of sandy soil to hold sufficient plant-available soil water to meet the transpiration demands of the crop during the rapid growing stages [43], which would have caused drought stress inducing stomatal closure hereby depressing photosynthesis. In addition, the results of this study cover two very different growth seasons where the rainfall was lower in 2014 than in 2013 (i.e., $216 \mathrm{~mm}$ vs. $256 \mathrm{~mm}$ ). In line with this, RUE observed on sandy soil was greater in 2013 than in 2014, while those on clay soil was similar between the two years (data not shown). An explanation could be that the clay soil holds much more plant available water and hence causing less severe drought stress to the crops. 
In addition to water availability, $\mathrm{N}$-fertilization level could also affect RUE and increase in $\mathrm{N}$ supply often results in an increase in RUE in wheat [44,45]. However, this was not the case in the present study as RUE was unaffected by $\mathrm{N}$-fertilization level on both clay and sandy soils, indicating that $\mathrm{N}$ availability is not a factor influencing RUE. One reason behind this could be that there was either a lot of initial mineral $\mathrm{N}$ in the soil or that a relatively large amount of $\mathrm{N}$ was released by mineralization, or both, which reduces the effect of the fertilization level. However, as we did not determine the soil mineral $\mathrm{N}$ content during the experiments it is not possible to explain the results explicitly. Nevertheless, here the wheat plants supplied with $200 \mathrm{~kg} \mathrm{~N} \mathrm{ha}^{-1}$ possessed greater DM and GY compared to those that received $100 \mathrm{~kg} \mathrm{~N} \mathrm{ha}^{-1}$, implying that other factors rather than RUE affecting DM accumulation and yield formation could have been influenced by $\mathrm{N}$ supply. Moreover, other abiotic factors, such as temperature [46], light intensity [47], water content and leaf mass per area [48], as well as vegetation types and coverage [49], also affect RUE. Therefore, the observed RUE could be an integrated result of the G $\times$ E x M interactions, while the water availability in the soil plays the leading role in affecting RUE.

The RUE is an important quantifier of crop production in relation to photosynthesis, as it combines both the amount of solar radiation captured by the crop and the efficiency of the crop to produce DM, while GY is the product of DM times HI. Therefore, GY can be increased by either increase in RUE or $\mathrm{HI}$ or both [12]. RUE has been used as an essential parameter in developing crop models based on solar energy-driven growth-engine where the models derive the crop biomass directly from the APAR and RUE [50]. However, a high variability of RUE has been found and the robustness of RUE to simulate biomass in crop models was constrained [51]. Later studies indicated that calculating biomass through water use efficiency was more robust than using RUE, highlighting the importance of water availability in affecting crop performance $[52,53]$. In line with this, the results of this study clearly demonstrate that RUE differed significantly between the two soil types, which was most likely due to differences in the amount of plant available water held in the two soils. Thus, for more accurate predication of crop growth under varied water availability, a combination of water-driven growth-engine with solar energy-driven growth engine would be crucial in developing crop growth models for future climate change scenarios.

In order to reveal the synergistic effect of the cultivar, soil type and N-fertilization level on measured variables, the PCA was performed. The PCA clearly illustrated the distinct clusters between the two soil types along the PC1, where all of the variables were positively contributing to the clustering of the clay soil. As has been mentioned previously, the high-water holding capacity of the clay soil would have caused less drought stress to the crops, resulting in greater values of DM, GY, HI and RUE than the plants grown on sandy soil. Therefore, instead of increasing $\mathrm{N}$ application, to sustain a good soil water status by supplemental irrigation at critical growth stages during the cropping season would enhance RUE and HI and consequently GY of wheat crops grown on sandy soil, and this merits further experimental studies.

\section{Conclusions}

To explore the $\mathrm{G} \times \mathrm{E} \times \mathrm{M}$ interactions on RUE is important in sustainable crop management in a future changing climate. The results of this field study demonstrate that RUE of spring wheat cultivars is highly affected by soil type, and most likely associated with the available water capacity of the soils. Thus, efficient soil water management in the field could be crucial for enhancing RUE and crop yield of spring wheat under Nordic conditions. 
Author Contributions: First author X.W. is responsible for the general writing of text and setup of text. S.C. has written parts of the text and contributed to the conceptualization of the study. J.S. conducted the field trials and collected the data. S.M.J. is responsible for data analysis and presentation. F.L. contributes to conceptualization of the study, interpretation of data, writing the original draft, review and editing of the manuscript. All authors have read and agreed to the published version of the manuscript.

Funding: The study was co-funded by the Ministry of Research and Innovation via the collaborative project MASCUR 'A detailed climate change risk assessment for European agriculture and food security, in collaboration with international projects' (project number 0603-00550B).

Conflicts of Interest: The authors declare no conflict of interest.

\section{References}

1. FAO. World Food and Agriculture—Statistical Pocketbook; FAO: Rome, Italy, 2018.

2. Fischer, R.A.; Rees, D.; Sayre, K.D.; Lu, Z.-M.; Condon, A.G.; Larque Saavedra, A. Wheat yield progress associated with higher stomatal conductance and photosynthetic rate, and cooler canopies. Crop Sci. 1998, 38, 1467-1475. [CrossRef]

3. Passioura, J.B. Grain yield, harvest index, and water use of wheat. J. Aust. Inst. Agric. Sci. 1977, 43, 117-120.

4. Duan, J.; Wu, Y.; Zhou, Y.; Ren, X.; Shao, Y.; Feng, W.; Zhu, Y.; He, L.; Guo, T. Approach to higher wheat yield in the Huang-Huai Plain: Improving post-anthesis productivity to increase harvest index. Front. Plant Sci. 2018, 9, 1457. [CrossRef] [PubMed]

5. Simpson, P.G.; Siddique, K.H.M. Soil type influences relative yield of barley and wheat in a Mediterranean-type environment. J. Agron. Crop Sci. 1994, 172, 147-160. [CrossRef]

6. Reynolds, M.; Foulkes, M.J.; Slafer, G.A.; Berry, P.; Parry, M.A.J.; Snape, J.W.; Angus, W.J. Raising yield potential in wheat. J. Exp. Bot. 2009, 60, 1899-1918. [CrossRef] [PubMed]

7. Fischer, R.A. Understanding the physiological basis of yield potential in wheat. J. Agric. Sci. 2007, 145, 99-113. [CrossRef]

8. Aisawi, K.A.B.; Reynolds, M.P.; Singh, R.P.; Foulkes, M.J. The physiological basis of the genetic progress in yield potential of CIMMYT spring wheat cultivars from 1966 to 2009. Crop Sci. 2015, 55, 1749-1764. [CrossRef]

9. Reynolds, M.; Foulkes, J.; Furbank, R.; Griffiths, S.; King, J.; Murchie, E.; Parry, M.; Slafer, G. Achieving yield gains in wheat. Plant Cell Environ. 2012, 35, 1799-1823. [CrossRef]

10. Flohr, B.M.; Hunt, J.R.; Kirkegaard, J.A.; Evans, J.R.; Lilley, J.M. Genotype×management strategies to stabilise the flowering time of wheat in the south-eastern Australian wheat belt. Crop Pasture Sci. 2018, 69, 547-560. [CrossRef]

11. Sinclair, T.R.; Muchow, R.C. Radiation use efficiency. Adv. Agron. 1999, 65, 215-265.

12. Stöckle, C.O.; Kemanian, A.R. Crop radiation capture and use efficiency: A framework for crop growth analysis. In Crop Physiology: Applications for Genetic Improvement and Agronomy; Sadras, V.O., Calderini, D.F., Burlinggton, N.J., Eds.; Elsevier: Amsterdam, The Netherlands, 2009; pp. 145-170.

13. Gregory, P.J.; Tennant, D.; Belford, R.K. Root and shoot growth, and water and light use efficiency of barley and wheat crops grown on a shallow duplex soil in a Mediterranean-type environment. Aust. J. Agric. Res. 1992, 43, 555-573. [CrossRef]

14. Yunusa, I.A.M.; Siddique, K.H.M.; Belford, R.K.; Karimi, M.M. Effect of canopy structure on efficiency of radiation interception and use in spring wheat cultivars during the preanthesis period in a Mediterranean-type environment. Field Crop. Res. 1993, 35, 113-122. [CrossRef]

15. Olesen, J.E.; Jørgensen, L.N.; Mortensen, J.V. Irrigation strategy, nitrogen application and fungicide control in winter wheat on a sandy soil. II. Radiation interception and conversion. J. Agric. Sci. Camb. 2000, 134, $13-23$. [CrossRef]

16. Andersen, M.N.; Munkholm, L.J.; Nielsen, L. Soil compaction limits root development, radiation-use efficiency and yield of three winter wheat (Triticum aestivum L.) cultivars. Acta Agric. Scand. Sec. B Soil Plant Sci. 2013, 5, 409-419.

17. Han, H.; Li, Z.; Ning, T.; Zhang, X.; Shan, Y.; Bai, M. Radiation use efficiency and yield of winter wheat under deficit irrigation in North China. Plant Soil Environ. 2008, 54, 313-319. [CrossRef] 
18. Li, Q.Q.; Chen, Y.H.; Liu, M.Y.; Zhou, X.B.; Yu, S.L.; Dong, B.D. Effects of irrigation and planting patterns on radiation use efficiency and yield of winter wheat in North China. Agric. Water Manag. 2008, 95, 469-476. [CrossRef]

19. Fischer, R.A. Irrigated spring wheat and timing and amount of nitrogen fertilizer. II. Physiology of grain yield response. Field Crop. Res. 1993, 33, 57-80. [CrossRef]

20. Abbate, P.E.; Andersen, F.H.; Culot, J.P. The effects of radiation and nitrogen on number of grains in wheat. J. Agric. Sci. Camb. 1995, 124, 351-360. [CrossRef]

21. Stöckle, C.O.; Kemanian, A.R. Can crop models identify critical gaps in genetics, environment, and management interactions? Front. Plant Sci. 2020, 11, 737. [CrossRef]

22. Yang, W.; Feng, H.; Zhang, X.; Zhang, J.; Doonan, J.H.; Batchelor, W.D.; Xiong, L.; Yan, J. Crop phenomics and high-throughput phenotyping: Past decades, current challenges, and future perspectives. Mol. Plant 2020, 13, 187-214. [CrossRef]

23. Svensgaard, J.; Roitsch, T.; Christensen, S. Development of a mobile multispectral imaging platform for precise field phenotyping. Agronomy 2014, 4, 322-336. [CrossRef]

24. Jensen, H.E.; Jensen, S.E. Jordfysik og Jordbrugsmeteorologi. In Det fysiske Miljø for Plantevækst; DSR Forlag: Frederiksberg, Danmark, 2001; ISBN 87-7432-584-1. (In Danish)

25. Jensen, S.M.; Svensgaard, J.; Ritz, C. Estimation of the harvest index and the relative water content-Two examples of composite variables in agronomy. Eur. J. Agron. 2020, 112, 125962. [CrossRef]

26. R Core Team. R: A Language and Environment for Statistical Computing; R Foundation for Statistical Computing: Vienna, Austria, 2019.

27. Pinheiro, J.; Bates, D.; DebRoy, S.; Sarkar, D.; R Core Team. Nlme: Linear and Nonlinear Mixed Effects Models; R Package Version 3.1-141; 2019. Available online: https:/CRAN.R-project.org/package=nlme (accessed on 13 September 2020).

28. Bates, D.; Mächler, M.; Bolker, B.; Walker, S. Fitting linear mixed-effects models using Lme4. J. Stat. Softw. 2015, 67, 1-48. [CrossRef]

29. Hothorn, T.; Bretz, F.; Westfall, P. Simultaneous Inference in General Parametric Models. Biom. J. 2008, 50, 346-363. [CrossRef] [PubMed]

30. Jensen, S.M.; Ritz, C. A Comparison of approaches for simultaneous inference of fixed effects for multiple outcomes using linear mixed models. Stat. Med. 2018, 37, 2474-2486. [CrossRef] [PubMed]

31. Nass, H.G. Harvest index as a selection criterion for grain yield in two spring wheat crosses grown at two population densities. Can. J. Plant Sci. 1980, 60, 1141-1146. [CrossRef]

32. Evans, L.T.; Fischer, R.A. Yield potential: Its definition, measurement, and significance. Crop Sci. 1999, 39, 1544-1551. [CrossRef]

33. Foulkes, M.J.; Reynolds, M.P.; Sylvester-Bradley, R. Genetic improvement of grain crops: Yield potential. In Crop Physiology: Applications for Genetic Improvement and Agronomy; Sadras, V.O., Calderini, D.F., Burlinggton, N.J., Eds.; Elsevier: Amsterdam, The Netherlands, 2009; pp. 355-385.

34. Wiesmeier, M.; Hübner, R.; Dechow, R.; Maier, H.; Spörlein, P.; Geuß, U.; Hangen, E.; Reischl, A.; Schilling, B.; von Lützow, M.; et al. Estimation of past and recent carbon input by crops into agricultural soils of southeast Germany. Eur. J. Agron. 2014, 61, 10-23. [CrossRef]

35. Austin, R.B.; Bingham, J.; Blackwell, R.D.; Evans, L.T.; Ford, M.A.; Morgan, C.L.; Taylor, M. Genetic improvement in winter wheat yield since 1900 and associated physiological changes. J. Agric. Sci. Camb. 1980, 94, 675-689. [CrossRef]

36. Aranjuelo, I.; Sanz-Saez, A.; Jauregui, I.; Irigoyen, J.J.; Araus, J.L.; Sánchez-Díaz, M.; Erice, G. Harvest index, a parameter conditioning responsiveness of wheat plants to elevated $\mathrm{CO}_{2}$. J. Exp. Bot. 2013, 64, 1879-1892. [CrossRef]

37. Ceotto, E.; Candilo, M.D.; Castelli, F.; Badeck, F.W.; Rizza, F.; Soave, C.; Volta, A.; Villani, G.; Marletto, V. Comparing solar radiation interception and use efficiency for the energy crops giant reed (Arundo donax L.) and sweet sorghum (Sorghum bicolor L. Moench). Field Crop. Res. 2013, 149, 159-166. [CrossRef]

38. Li, Y.; Tang, L.; Zhang, Y.; Zhu, X.; Cao, W.; Zhu, Y. Relationship of PAR interception of canopy to leaf area and yield in rice. Sci. Agric. Sin. 2010, 43, 3296-3305.

39. Stockle, C.O.; Kiniry, J.R. Variability in crop radiation-use efficiency associated with vapor-pressure deficit. Field Crop. Res. 1990, 25, 171-181. [CrossRef] 
40. Rasmussen, J.; Ntakos, G.; Nielsen, J.; Svensgaard, J.; Poulsen, R.N.; Christensen, S. Are vegetation indices derived from consumer-grade cameras mounted on UAVs sufficiently reliable for assessing experimental plots? Eur. J. Agron. 2016, 74, 75-92. [CrossRef]

41. Calderini, D.F.; Dreccer, M.F.; Slafer, G.A. Consequences of breeding on biomass, radiation interception and radiation-use efficiency in wheat. Field Crops Res. 1997, 52, 271-281. [CrossRef]

42. Estrada-Campuzano, G.; Miralles, D.J.; Slafer, G.A. Genotypic variability and response to water stress of preand post-anthesis phases in triticale. Eur. J. Agron. 2008, 28, 171-177. [CrossRef]

43. Suzuki, S.; Noble, A.D.; Ruaysoongnern, S.; Chinabut, N. Improvement in water-holding capacity and structural stability of a sandy soil in Northeast Thailand. Arid Land Res. Manag. 2007, 21, 37-49. [CrossRef]

44. Green, C.F. Nitrogen nutrition and wheat growth in relation to absorbed solar radiation. Agric. For. Meteorol. 1987, 41, 207-248. [CrossRef]

45. Garcia, R.; Kanemasu, E.T.; Blad, B.L.; Bauer, A.; Hatfield, J.L.; Major, D.J.; Reginato, R.J.; Hubbard, K.G. Interception and use efficiency of light in winter wheat under different nitrogen regimes. Agric. For. Meteorol. 1988, 44, 175-186. [CrossRef]

46. Christensen, S. Non-destructive assessment of growth parameters in spring barley. Eur. J. Agron. 1992, 1, 187-193. [CrossRef]

47. Odabas, M.S.; Radusiene, J.; Cirak, C.; Camas, N. Prediction models for the phenolic contents in some Hypericum species from Turkey. Asian J. Chem. 2008, 20, 4792-4802.

48. Rosati, A.; Badeck, F.; Dejong, T. Estimating canopy light interception and absorption using leaf mass per unit leaf area in Solanum melongena. Ann. Bot. 2001, 88, 101-109. [CrossRef]

49. Zhu, W.; Pan, Y.; He, H.; Yu, D.; Hu, H. Simulation of maximum light use efficiency for some typical vegetation types in China. Chin. Sci. Bull. 2006, 51, 457-463. [CrossRef]

50. Jones, J.W.; Hoogenboom, G.; Porter, C.H.; Boote, K.J.; Batchelor, W.D.; Hunt, L.; Wilkens, P.W.; Singh, U.; Gijsman, A.J.; Ritchie, J.T. The DSSAT cropping system model. Eur. J. Agron. 2003, 18, 235-265. [CrossRef]

51. Steduto, P.; Albrizio, R. Resource use efficiency of field-grown sunflower, sorghum, wheat and chickpea: II. water use efficiency and comparison with radiation use efficiency. Agric. For. Meteorol. 2005, 130, $269-281$. [CrossRef]

52. Steduto, P.; Hsiao, T.C.; Fereres, E. On the conservative behavior of biomass water productivity. Irrig. Sci. 2007, 25, 189-207. [CrossRef]

53. Steduto, P.; Hsiao, T.C.; Raes, D.; Fereres, E. AquaCrop-The FaO crop model to simulate yield response to water: I. Concepts and underlying principles. Agron. J. 2009, 101, 426-437. [CrossRef]

(C) 2020 by the authors. Licensee MDPI, Basel, Switzerland. This article is an open access article distributed under the terms and conditions of the Creative Commons Attribution (CC BY) license (http://creativecommons.org/licenses/by/4.0/). 